\title{
Fur and Sustainability
}

Oxymoron or Key to 'Deeper' Luxury?

Csaba, Fabian Faurholt; Skjold, Else

\section{Document Version}

Accepted author manuscript

Published in:

Journal of Design Business \& Society

DOI:

10.1386/dbs.4.2.131_1

Publication date:

2018

License

Unspecified

Citation for published version (APA):

Csaba, F. F., \& Skjold, E. (2018). Fur and Sustainability: Oxymoron or Key to 'Deeper' Luxury? Journal of Design Business \& Society, 4(2), 131-149. https://doi.org/10.1386/dbs.4.2.131_1

Link to publication in CBS Research Portal

\section{General rights}

Copyright and moral rights for the publications made accessible in the public portal are retained by the authors and/or other copyright owners and it is a condition of accessing publications that users recognise and abide by the legal requirements associated with these rights.

Take down policy

If you believe that this document breaches copyright please contact us (research.lib@cbs.dk) providing details, and we will remove access to the work immediately and investigate your claim. 


\section{Fur and Sustainability: Oxymoron or Key to 'Deeper' Luxury?}

\section{Fabian Faurholt Esaba and Else Skjold}

Journal article (Accepted manuscript*)

\section{Please cite this article as:}

Csaba, F. F., \& Skjold, E. (2018). Fur and Sustainability: Oxymoron or Key to 'Deeper' Luxury? Journal of Design Business \& Society, 412), 131-149. D01: 10.1386/dbs.4.2.131_1

DOI: $10.1386 / d b s .4 .2 .131 \_1$

Uploaded in accordance with the Open Access Policy of Intellect:

https://wwww.intellectbooks.com/open-access\#journalsopenaccess

* This version of the article has been accepted for publication and undergone full peer review but has not been through the copyediting, typesetting, pagination and proofreading process, which may lead to differences between this version and the publisher's final version AKA Version of Record. 


\title{
Fur and Sustainability - Oxymoron or Key to 'Deeper' Luxury?
}

\author{
Fabian Faurholt Csaba, Associate Professor, Department for Intercultural Communication and \\ Management, Copenhagen Business School, Dalgas Have 15, 2000 Frederiksberg, Denmark. \\ fc.msc@cbs.dk
}

Else Skjold, Assistant Professor, Department for Education and Research at Design School Kolding, Aagade 10,6000 Kolding, Denmark. esk@dskd.dk

This article explores the notion of deeper luxury, which insists that 'real' luxury should involve sustainable practices in the production and consumption of luxury goods. It traces historical and recent developments in the field of fur to understand the implications, uncertainties and ambiguities of luxury's confrontation with sustainability. Considering fur in relation to future standards for luxury products, we raise questions about moral problematisation and justification of luxury in terms of sustainability. We first examine the encounter of luxury with sustainability and explain the significance of the notion of 'deeper luxury'. After taking stock of the impact of sustainability on luxury and various directions in which sustainable luxury is evolving, we discuss concepts of sustainable development in relation to the history of moral problematisation of luxury. This leads to the case of fur as material used to establish social distinctions from at least medieval times to the present and subject to moral condemnation and controversy. Our case inquiry reviews recent research projects and industry initiatives that seek to determine whether the fur can be seen as sustainable or not. The article discusses whether fur is about to lose or reclaim its legitimacy in an era of sustainable luxury, and concludes with reflections on depth and sustainable luxury.

\section{Introduction}

Luxury has - with varying degrees of intensity - been the subject of moral problematisation ever since antiquity. In recent decades, moral debates of luxury have increasingly been framed in terms of sustainability and have called into question corporate conduct in the luxury industries as well as the social and environmental implications of luxury consumption. The confrontation of luxury with sustainability raises fundamental questions about how - and how well - the two blend: How is sustainability reshaping contemporary luxury? To what extent can luxury be justified as sustainable? We investigate the implications of luxury's encounter with sustainability through the case of the fur. While fur in many senses epitomizes luxury, the fur business represents an extreme case as its very legitimacy and license to operate is at stake. Paradoxically, environmental concerns related to animal rights threaten its very existence, while another line of environmental reasoning is being used to justify fur. In other words, the case illustrates the potential impact of sustainable development(s) in the luxury industries, but also how ambiguous and contested a concept sustainability is. 


\section{Towards a 'Deeper Luxury'}

In recent years, several studies in luxury management, branding and consumer behavior have addressed the relationship between luxury and sustainability and the luxury industry's response to the agenda outlined in the World Commission on Environment and Development's groundbreaking report (1987). A common starting point of inquiries are efforts to define concepts of luxury and sustainability and observations on their apparent contradictory or even antithetical nature. Luxury's associations with ostentation, irrationality, excess, indulgence, waste, discrimination and social stratification are juxtaposed with the components and values that define sustainability, including moderation, frugality, fairness and social harmony and equity. While acknowledging these tensions, studies typically point to central traits of luxury that correspond well with sustainable development - rarity, beauty, durability, high quality and deeper values which promise to bring the luxury industry to the forefront of sustainable business practice in the future (Kapferer and Michaut 2015; Hennigs et al. 2014). Our case confronts us with complications that force us to interrogate the combination of luxury and sustainability further. This involves exploring the boundaries, compromises and contentious aspects of the sustainable development discourse, and the role of sustainability in legitimizing as much as problematizing the luxury industry.

If, as different observers insist, a paradigm shift is taking place in the luxury industry (Hennig et al. 2013; Luca 2014; Carrigan 2013), it has been slow to come about. In their analysis of the luxury industry's response to the sustainability agenda, Kapferer and Michaut-Denizeau (2014) argue that most of the prominent luxury brand companies had by 2000 quietly taken steps to address sustainability without communicating about their initiatives (see Kering 2014). The industry preferred to focus its communication on maintaining the 'dream image' of luxury products, rather than raise more serious issues. This discreet approach was made possible by the industry structure and ownership. Family owned luxury companies were not obliged to report their strategic initiatives and the large luxury conglomerates had decentralized structures, which meant that sustainability was not dealt with at a corporate level by a designated corporate social responsibility unit, but left to individual luxury brand businesses. Furthermore, advocacy groups and activists tended to target big brands in the mass-markets, which due to the size and nature of their businesses were more exposed criticism on issues such as labor conditions and environmental performance (Kapferer and Michaut-Denizeau 2014). There is also little evidence that luxury consumers paid much attention to sustainability issues in their purchases and consumption of luxury goods. This meant that luxury for long was not confronted with sustainability issues.

The publication of a report written for World Wildlife Foundation (WWF) in the UK is considered instrumental in forcing issues of sustainability in luxury in to the open (Kapferer 2010; Streit and Davies 2013; Luca 2014). In the report entitled 'Deeper Luxury - quality and style when the world matters', Bendell and Kleanthous (2007) make the business case for a new approach to luxury - a deeper luxury - appealing to a global educated elite concerned about environmental and social issues. Luxury brands, in Bendell and Kleanthous' analysis, face challenges in retaining exclusivity in an age of democratized luxury and social legitimacy in a world with increasing inequality. Invoking the figure of 'splendour amid squalor' to counterpose the alluring images of luxury with 
those of unequal social and economic development and environmental degradation, they insist that luxury brands have both the obligation and power to influence consumer aspirations and choices to promote sustainable consumption (Bendell and Kleanthous 2007: 2). To underline the urgency of their appeal and identify the luxury industry must take, they rated the ten largest, publicly-traded luxury brand-owning companies on two categories of data (a) their environmental, social and governance performance as reported to the ethical investment community and (b) media and non-governmental organisations coverage of positive and negative news stories about companies. No grades over C+ were awarded (Bendell and Kleanthous 2007: 34). The methodology of the report, as well as its motives and omission, provoked strong reactions. The Responsible Jewelry Council (RJC) representing prominent luxury players such as Bulgari, Cartier, LVMH) and Tiffany \& Co., accused the scoring methodology for being 'fatally flawed, based as it is on a seemingly perfunctory review of company and media websites, with no actual direct consultation with the companies named in the report' (Miller 2007). The organization was especially upset by the report's failure to acknowledge the gold and diamond industry's prosustainability initiatives undertaken in collaboration with NGOs such as Oxfam and Conservation International as well as WWF itself (Miller 2007). But the report received massive media coverage, was taken up in industry institutions like the International Herald Tribune Luxury Conference (New Delhi 2009) and was followed by announcements of further commitment among luxury players most notably luxury group PPR (formerly known as Pinault-Printemps-Redoute and renamed Kering in 2013) to improving sustainability (CSR Wire 2007).

Other activist organizations have followed suit and no longer shy away from targeting the luxury industry. An example is a report for Ethical Consumer Research Association (Moore 2011), which rated a line-up of the top fifteen designer fashion brands on their performance on fifteen ethical criteria ranging from animal and human right and the environment to political activities such as lobbying. None of them received more than seven of twenty, and the grade point average was four-point-five of twenty. No doubt, the methodology and other aspects of this study could be challenged and dissected, but the fact that none of the 15 companies surveyed responded to the questionnaire they were sent (Moore 2011: 11), casts doubt on the depth of the sector's commitment to engage with critical stakeholders on issues of sustainability.

Nowhere has the controversy over the environmental and social issues in contemporary luxury been as heated as when it comes to the use of animal fur in luxury fashion. Of course, the great fur war started long before the luxury industry was confronted with sustainable development. Animal rights organizations such as PETA and ANIMA, with roots in the 60s countercultural movement, have polarized debates about the use of fur in luxury fashion garments since the 1970s within the fashion industry as well as in the general public (Olson and Goodnight 1994). At present, the luxury fashion sector still appears deeply divided. While some, as Gucci, Michael Kors, Jimmi Choo, Georgio Armani, Ralph Lauren or Calvin Klein have chosen to go fur-free, others such as Chanel, Fendi or Burberry continue to make use of fur in their designs. The relationship between the antifur controversy and sustainable luxury agenda is rather complex. Later, we seek to clarify the animal rights cause's place in the sustainability discourse and explore implications of the argument that it was fur's association with middle-aged, middle-class femininity - as much as concerns for animal welfare - which made fur the prime target of animal rights criticism (Skov 2005: 12). But we argue that sustainability, as it has emerged as the main conceptual frame for the moral 
problematisation of luxury, has absorbed or marginalized the animal rights cause and other lines of criticism of luxury.

The fur industry seems to be in the paradoxical situation, that the sustainable agenda with its heightened focus on social and environmental issues could spell the end for it, or actually legitimize fur as a model for new eco-sustainable material practices in garment sector at large. If fur's durability as a material and long-standing appeal and rich heritage as a luxury item outweighs concerns for the plight of animals and related symbolic associations, it could come to represent the embodiment of sustainable luxury. As luxury group Kering's Chief Sustainability Officer suggests:

Sustainability is embedded in the very concept of luxury. A cornerstone of luxury is the longlasting endurance of an item. And one of the key roles of our industry is to beautify the world, we have no greater responsibility than to do so ethically and sustainably.

(Daveu 2014)

In other words, as the concept of sustainable luxury evolves, fur might either be excluded, or placed at its center. This conundrum points to the multifaceted and contested nature of sustainability.

\section{Sustainability's impact on contemporary luxury}

How is sustainability then reshaping contemporary luxury? Sustainability is most certainly on the agenda of the luxury industry, and to some regard recent developments a paradigm shift in which sustainability is becoming an essential part of luxury (Hennigs et al. 2013).

Godart and Seong (2015) in an analysis of luxury fashion, introduce three emerging scenarios of 'eco-sustainability', each demonstrating different ways of developing and implementing more or less market-based solutions to eco-sustainability. They are 1) institutional change through slow luxury fashion; 2) innovative luxury fashion; and 3) upgrading luxury fashion through regulation. The three scenarios can be extended beyond luxury fashion and eco-sustainability, however in the process, the path towards reconciling sustainability and luxury complicates.

They explain the first scenario as a 'degrowth' strategy in which trend cycles are decelerated, producers are motivated to focus on designs with lasting appeals, and consumers to keep their clothes for a longer period of time (Godart and Seong 2015). Janssen et al. point to this path as a strategy for luxury: 'Our findings suggest luxury brands might want to embrace the slow fashion movement' (cf. fast fashion trends prevailing currently), in which products are 'made by hand and meant to endure for decades' (2014: 53). For them, this means that the luxury industry must abandon the 'ongoing democratization of luxury brands in search of higher profits [... and] keep their enduring products scarce' not only to preserve their luxury character, but also to make their perceive alliance with CSR effort more credible (Janssen et al. 2014: 52). Kapferer and Michaut embrace the represents a return to an older, 'true' luxury. In what sounds like an invention of luxury tradition, they argue: 
Whereas luxury historically aligned with sustainability ideals [...] by producing rare products of ultra-high quality, made by hand and with respect for tradition, it has come to look more like consumer or fashion goods, made to fill trash bins after they achieve structural and rapid obsolescence.

(Kapferer \& Michaut-Denizeau 2014: 6)

By employing a narrow definition of luxury, they move the problem of sustainability away from 'true luxury': 'Therefore, the real issue entails the sustainability of this new form of mass luxury' (Kapferer \& Michaut-Denizeau 2014: 6).

The second scenario, innovative luxury fashion, rather than slowing fashion cycles, seeks to achieve eco-sustainable improvements through innovative use of low impact materials, efficiency in production and recycling. Rather than returning to a narrower more exclusive notion of luxury, this scenario focuses on disruptive business models and conceptions of luxury. Jem Bendell (of Deeper Luxury) and Laetitia Thomas (2013) propose the concept of 'elegant disruption' and explore cases range from Tesla to upstart enterprises from around the world, who are breaking new ground in sustainable luxury. With special reference to the Latin American context, Gardetti sees these 'Emerging Davids' as transformational leaders whereas 'Established Goliaths' are reactive in their attitude towards sustainability and making only slow progress in improving their social and environment impact (Gardetti and Girón 2014: 11).

While the 'innovative luxury fashion'-scenario emphasizes actors who innovate and disrupt, and as such break the rules, the third scenario relies on industry-wide enforcement of rules to ensure more eco-sustainable luxury. Godart and Seong (2015) suggest that self-regulation of industry actors and civil society initiatives (such as the Higg index) play a central role in this scenario, but necessarily must be backed by public authorities.

Godart and Seong conclude that these three scenarios might 'already be, to some extent, in place', but believe they are 'for the most part, still to be implemented' (2015: 21). They suggest that accomplishing eco-sustainability through some combination of slow luxury fashion; innovative luxury fashion; and upgrading luxury fashion through regulation risks brushing against core principles of fashion, which they consider 'an institutional force that has been continuing since the birth of fashion' (Godart and Seong 2015, 24).

Contrary to Kapferer (2010), who suggests that luxury and fashion represent different temporal logics and can be divided, we believe that the analysis of scenarios in luxury fashion can be applied more broadly to the luxury industry. As Trentmann (2012) argues, luxury and fashion have been intertwined since the beginning of modernity; fashion goods emerged out of the markets and institutions for luxury goods in the $17^{\text {th }}$ century, and over the next century fashion became part of the language of luxury. The separation of fashion and luxury certainly doesn't make sense in case of fur, although Skov (2005) argues it is only fairly recently, the traditional fur business has been incorporated fully into luxury fashion. However, it is necessary to stress that Godart and Seong refer to eco-sustainability, and in that regards focus on the environmental dimension of sustainability. Further consideration of sustainability's economic and social dimensions complicates the analysis of sustainable luxury greatly. In the next section, we will address the 
different dimensions and societal objectives of sustainable development, and explore the tensions between different approaches to sustainability that disagree in their prioritizations or understanding of the three main dimensions. This mapping of sustainable development will help us situate various notions of sustainable luxury, as well as reflect upon the criteria for labeling luxuries as sustainable in various orientations towards sustainability.

\section{Sustainable development - a contested term}

Steve Connelly (2007) asserts that sustainable development is an ambiguous and contested term, but observes that many representations and analyses of sustainability obscure the complexity of the concept. He believes, it has 'a widely accepted but vague core meaning within which there are differing 'conceptions of the concept'-legitimate, yet incompatible and contested, interpretations of how the concept should be put into practice' (Connelly 2007: 262)

Early efforts to represent sustainable development figuratively, visualized it as the intersection of three overlapping circles representing concerns connected with the economy, society and the environment respectively. Others represent it as a spectrum from 'weak' to 'strong' sustainability - expressing the degree of commitment to environmental and social agendas over economic considerations, or as a two-dimensional map with equality/social justice one axis, degree of environmental concerns on the other (Connelly 2007; Hopwood et al. 2005).

Connelly proposes a map of sustainable development as a triangular field with extreme viewpoints on economic growth (with no concern for environmental or social costs), environmental protection (at any economic and social cost), and social justice (at any economic or environmental cost) respectively, represented at each corner. The map allows us to locate certain positions and debates, and discuss what lies at the margins or outside the boundaries of what qualifies as sustainability. Sustainable development was built on principles of balancing social justice, economic development and environmental stewardship and therefore occupies an area in the middle of the triangle (Connelly 2007; World Commission on Environment and Development 1987). Connelly suggest that the area close to the environmental protection corner, represents a 'deep Green' or deep ecology position that rejects sustainable development as too great a compromise and prioritizes the natural world over considerations of social equity and growth. Classical formulations of sustainability have been accused of being anthropocentric; as we move close to environmental protection corner, we cross over to an eco-centric view (Imran et al. 2014). The animal rights movement (which we will later associate with a zoocentric view), probably fits in here, but to the extent that animal rights is regarded as the extension of social justice and moral consideration to 'non-human' animals, it might be placed closer to the social justice corner. Social justice should be understood equity in broad terms, to comprise not only class divisions, but also north-south, gender, intergenerational etc. equity. 'Weak' sustainability is close to the economic growth corner. When we move further away from this corner, we might talk about a strong sustainability. The line of the triangle connecting the economic growth and environmental protection corner represents 'ecologic modernization', whereas Connelly (2007) associates the line from the environmental protection corner to the social justice corner with eco-socialism. The remaining line represents the traditional growth/equity-debate discussing the creation and 
redistribution wealth in society, without consideration of the environment. This debate has been essential in the critique and justification of luxury, historically (see fig. 1).

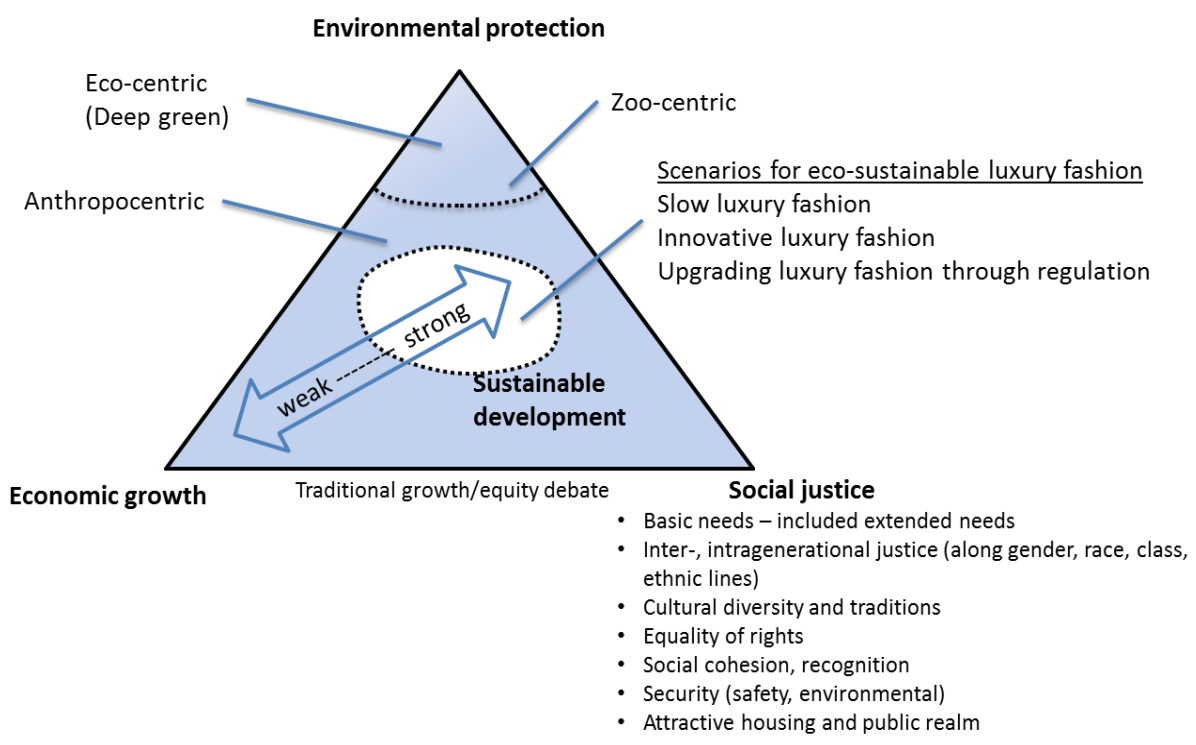

Fig. 1: Sustainable development and luxury (based on Connolly 2007 p.270)

The studies on sustainable luxury, we have reviewed, recognize that sustainable development combines environmental, social and economic objectives but tend to pass lightly over ambiguities and conflicts between various approaches to sustainable development. As observed, Godart and Seong (2015) consider scenarios of 'eco-sustainability' and acknowledge that they are preoccupied with environmental challenges, not other aspects. But as it became clear, the studies of sustainable luxury we associated with the two first scenarios, differed substantially with regards to their position on social equality as well as approach to economic development.

The Deeper Luxury-report is fairly balanced in its concerns for social issues, economical opportunities and environmental preservation, but hardly addresses animal rights. In this sense, it echoes the dominant anthropomorphic orientation in sustainable development discourse. It is not 'deep' in the sense of 'deep ecology' and does not address the challenges of reconciling the different dimensions in sustainability.

\section{Sustainability as the 'Remoralisation' of Luxury}

From the first literate societies until high modernity the figure of Luxury has excited moral condemnation and stimulated the regulatory reflex. The moralization of luxury has exhibited remarkable persistence. The invocation of luxury is one of the most ancient and most pervasive negative principles around and through which social criticism and regulatory activity has been articulated. 
We have suggested that discourse of sustainability has confronted luxury with moral issues, which the luxury industry previously, or at least for a long time, seems to have been able to evade. As the case of fur illustrates this is not entirely accurate. In fact, we might suggest that the environmental and conservationist values and movement which sustainability grew out of, emerged partly in response to the excesses of the fur trade in 'Age of Extermination' (Dolin 2010).

In his magisterial account of the history of the idea of luxury, Christopher Berry (1994) argues that 'luxury' from its inception in Greek thought was a political concept, subject to deep moral concern. Luxuries were condemned for fostering effeminacy and thereby undermining virtue, corrupting both the individual and society. This line of criticism of luxury persisted throughout the Roman, Christian and early modern eras, and luxury carried mainly negative connotations at least up until the seventeenth century, where liberal thinkers began to make the controversial argument that aspirations to a life of luxury were natural, perhaps even a mark of civilization. Debates over luxury raged in the $18^{\text {th }}$ Century, but gradually settled as Adam Smith's argument that individual greed and acquisitiveness were necessary prerequisites for the stimulation of the economy' gained currency, and human well-being came to be conceived in terms of economics, rather than a moral or religious basis (Hilton 2004: 102). Berry refers to this process as the 'de-moralisation of luxury' (1994: 101).

The liberalist legitimization of luxury has not entirely eradicated the classical lines of critique, but according to Berry criticism of luxury in the modern era focuses on the obligation to meet needs. He observes that the socialist critique of luxury, 'invokes the morality of meeting needs to indict a society that supports the ability to acquire luxuries ahead of the responsibility of ensuring that needs are met' (1994: 20-21). The Brundtland report (World Commission on Environment and Development, 1987) does something similar when it emphasizes our moral obligation to give priority to fulfilling the basic needs of the world's poor. But as Hunt suggested, 'We retain a vague sense of "luxury" as a problematic category. For us it combines some lingering sense of censure with a positive attention [...] the idea of being pampered and indulged makes [it] a potent stimulant' (1995: 359). The question is how sustainability debates have contributed to 'remoralise' luxury.

In coming to terms with the confrontation of luxury with sustainability, we find it instructive to consider the history of moral debates of luxury to better understand the deep-rooted connotations and underlying frames that shape our judgments and justifications of luxury. While environmental concerns are relatively new in debates on luxury, the sustainability agenda regards environmental problems as are deeply entangled with social and economic issues, which have been addressed in the moral criticism and justification of luxury in the past. To the extent that recent moral consideration of luxury has revolved mainly around the traditional growth/equitydebate, the environmental aspect in the sustainable development discourse has added a new dimension to the critique of luxury. This becomes clearer in the case of fur.

\section{Fur as luxury - from medieval European courts to 20th Century celebrity culture}


When looking at the use of fur in garments, the moral discussions between fur as 'necessary' and excessive/symbolic can be traced back to at least the middle ages. Danish costume historian Camilla Louise Dahl describes strict regulations for the use of various types of fur according to social ranks already in 15th and 16th Century Scandinavia. Hence, only royals and court members were allowed to use the fur from smaller animals such as squirrel, marten, sable or ermine, whereas the remaining population wore fur from fox, cat, wolf, sheep, or other larger animals. Particularly the winter skin from the belly of the Nordic grey squirrel - also referred to as 'vair' was very costly, as it took considerable amounts of animals to make a full costume (Dahl 2010). Also, while royals and court members wore the fur as inside lining for their silk garments, and perhaps as mere decoration on collars or cuffs, the average population wore the fur with the hairs on the outside. American cultural historian Julia V. Emberly (1998) confirms this with evidence from the English courts during the same period in which similar sumptuary laws were enforced. Most interesting in relation to our era, these laws were specifically aimed at male court members, as female court members by and large followed the standards and fashions for menswear, which at the time were excessive and highly flamboyant. This continued in spite of a wave of puritanism in the 16th Century, which problematized the effeminacy of male court costumes (Emberly 1998: 61). Thus, during the French Revolutionary wars, a decree was made to tone down the luxurious quality of Italian knights' costumes, as they were so decorated with hair ribbons, jewelry on shoes and costumes, artificial flowers or lace sleeves, that the wars became known as 'the lace wars' (Aspesi 2000). As such, the history of fur has, in the words of museum curator Andrew Bolton, '...been central in negotiations about social difference; not only a sign of wealth but class, gender, and religious hierarchies...[and as such]...animal skins, prints and symbolism appear in fashion at times of sociopolitical turmoil' (Bolton 2005:11). However, from the 19th Century and onwards, fur can be said to symbolize in particular the social differences of gender. With the emergence of the suit and the so-called 'Great Masculine Renounciation' in J. C. Flügel's words (1931 in Hollander 1994), the role of fur changed and has since been increasingly associated with the feminine. This coincided with the rise of Haute Couture fashion in Paris from the mid-19th Century, which ever since has linked the general idea of fashion to women (e.g. Rocamora 2009). As Bolton states, this development also means that menswear fur has become more or less sidelined, relating mainly to ideas of (capitalist) aristocracy, or to the fighting/military man; the 'stereotype of fur-clad man' is the mogul or capitalist clad in coats of 'sheepskin or other coarse fur, most notably bear, goat, wolf, beaver or racoon'. The only exception in recent time is represented in the so-called 'pimp style' worn by hiphop male celebrities such as P. Diddy or 50 Cent in the 1990s and 2000s (Bolton 2005: 49).

According to Bolton, fur was particularly in vogue in the $1930 \mathrm{~s}, 60 \mathrm{~s}, 80 \mathrm{~s}$ and the $2000 \mathrm{~s}$, since these periods represent decades of social change. However, this argument fails to note that fur became a marker of status for particularly the nouveau-riche of the rising industrialism in Europe and America in the 19th Century (Municchi 1992). Because it is here that fur becomes inextricably associated with Western, upper class women, as well as with what Emberly defines as the 'political and libidinal economies of fur' (1998: 17). Hence, fur garments became the perfect 'gift' to a passive female figure all the way from 19th Century up to the 1960s: from courtesans and mistresses to tempting, sexual goddesses of Hollywood and the rising celebrity culture of the 
1930's, and over to the 'respectable' women of society, be they the wives of tycoons of early industrialism or of aspiring middle-class men in the 1960s.

This development is closely tied with the way in which the tactility and conspicuous quality of fur acquires connotations to female sexuality, and thus come to play a vital part in the symbolic oppression and exploitation of women, of nature, and all that is considered non-Western and nonrational; everything that feminist writer Simone de Beauvoir termed the rational, industrialist man's 'other' (1998 [1952]). It is exactly these connotations that paved the way for the success of fur in late 19th Century and early-mid 20th Century (women's) fashion. And it is the same connotations that have caused such controversy from the 1960's and onwards, as the fur-clad, upper class women became the symbol of everything that was wrong in society. In the revolts against male dominance, capitalist logics, imperialism and anthropocentrism, the fur-clad, upper class woman became both victim and villain, oppressed and oppressor; at the same time a 'fossilized' and 'pill-popping tragedienne' of the 1950s (Bolton 2005: 62-63) and 'derisive spectacle of [..] demon-like consumerism' (Emberly 1998: 15). As such, the passive female figure became depicted by e.g. British animal rights group Lynx as stupid victims of fashion marketing, responsible for the cruel death of animals because of their hedonistic indulgence with fashion glamour.

\section{Discussion: Fur and Sustainability}

As Skov (2009) has argued, the overall stance of the movement against the use of fur is that it is not necessary in industrial society, whereas it is in indigenous cultures with no alternatives. In this way, the material of fur gets tightly linked to Veblen's 'conspicuous consumption' and belief that human vanity and search for status as cynical and cruel - an idea that is currently being picked up within debates of sustainability which has an inbuilt critique of the current fashion system (Entwistle 2014). This type of critique is closely linked to traditional moral debates about luxury, but also to debates about the role of man on our planet. As Olson and Goodnight show, the role of the anti-fur movements as defenders of the 'unrepresented' animals can be traced back to a critique of Kant's idea that, '[...] animals exist only to a means to an end. And that end is man' (Kant quoted in Olson \& Goodnight 1994: 253). According to these authors, as well as Skov (2009), the downfall or revitalisation of the fur sector lies in the consumers' hands; whether they find fur garments fashionable or not. Hence, sustainability must be linked to fashionability in order to appeal. This shows that the debate for or against fur is highly complex and filled with tensions - as we have shown how sustainability is an ambiguous, contested not yet fully defined notion. As an example, Kozlowski et al. (2012) demonstrates that working with sustainability in the fashion industry cannot be confined to one particular phase of the product life cycle, such as (typically) the phase of raw material acquisition, the phase of raw material processing and manufacturing, or the phase of apparel production. It must also address the phases of distribution and retail, consumer use, and disposal (Kozlowski et al. 2012: 27).

Applying the life cycle analysis (or similar methods) to fur in arguments for and against fur and sustainability increases complexity and polarization in the debates. If we follow Kozlowski et al.'s argument, one might say that the assessment of the sustainability of fur must be based on presale phases of the life cycle, namely raw material acquisition, raw material processing and 
manufacturing, and apparel production. When following the arguments of animal rights organizations Bont voor Dieren, GAIA and LAV1 their Life-cycle analysis report goes 'from chicken feed to piece of fur', comparing $1 \mathrm{~kg}$ of fur with $1 \mathrm{~kg}$ of what they term 'common textiles' (Bijleveld and Korteland 2011). They conclude that fur production pollutes up to 5 times more than textiles, contradicting the claim of the fur industry that fur is more environmental friendly because it is a natural material. Others, such as Plannthin (2015), argue against the farming of animals entirely, as they perceive this type human treatment of animals as ethically wrong. According to Plannthin (following Leena Vilkka), 'animal welfare is based on zoocentrism, a philosophy where issues, concepts and values of animals are central, in contrast to anthropocentrism, which centers on the value of humans' (2015: 58).

In order to counter such arguments, the fur industry has been establishing various initiatives to ensure transparency, better animal welfare and minimum negative environmental impact of fur farming. In Europe alone, this is currently being done as an attempt to promote the European fur sector as particularly 'sustainable'. Thus, the international industry association Fur Europe (fureuope.eu) was established to develop a sustainable roadmap, rooted mainly in the animal welfare assessment-programme WelFur initiated by the EFBA4 (see fig. 2). Also here, the life-cycle analysis model of Fur Europe/EFBA has its focus on the pre-sale phases defined by Kozlowski et al. (2012)

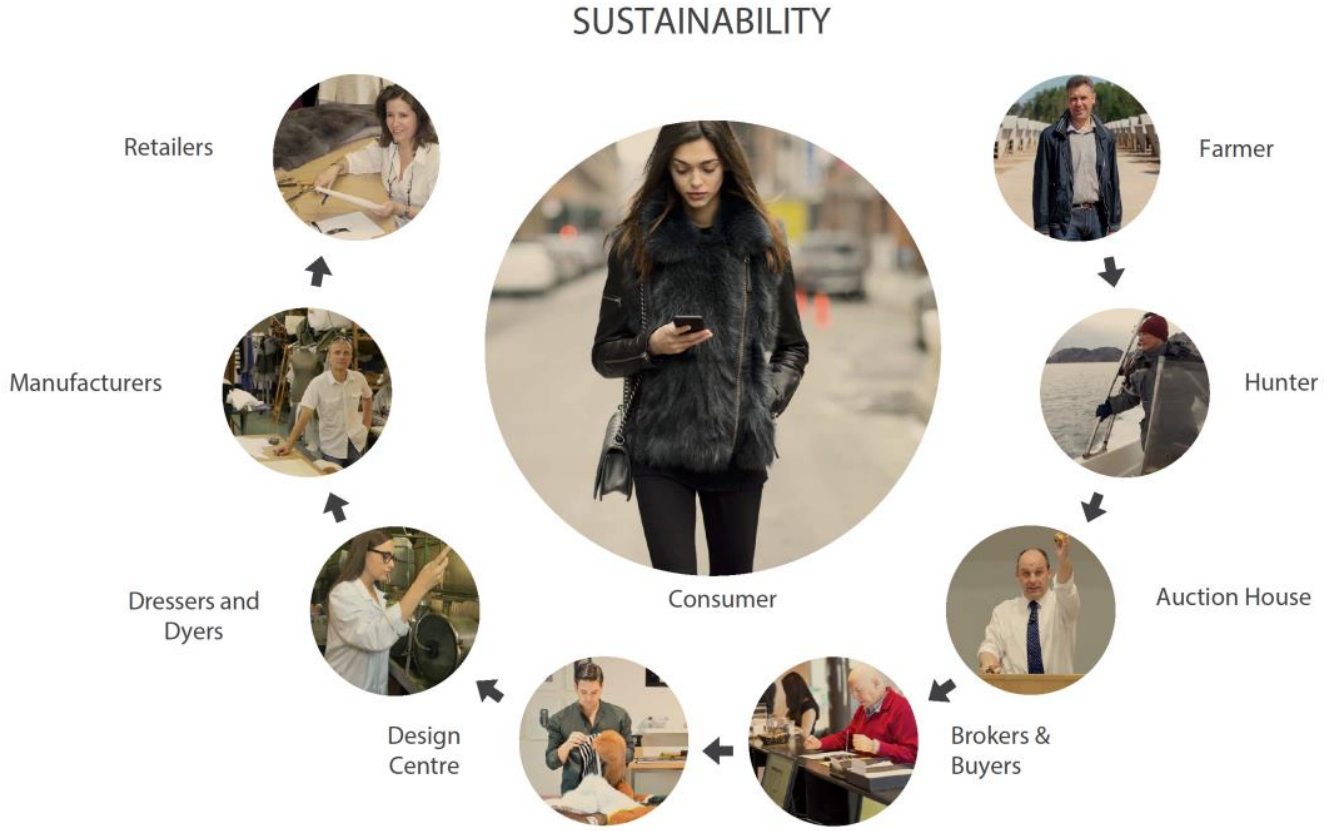

Fig 2: Model fra 2016 med pelsens livscyklus med tilladelse fra Fur Europe - får det I morgen, eventuelt med nye inputs... 
If looking at arguments on fur and sustainability in the post-sale phases of the fur life-cycle analysis defined by Kozlowski et al. (2012) as distribution and retail, consumer use, and disposal, there is some, but relatively less debate and initiatives. When looking at the argument of the fur industry, the longevity of fur as material (in average 30+ years in people's wardrobes) and the fact that fur as a natural material is potentially biodegradable, makes it a more sustainable choice per se (IFTF 2012). Against this Plannthin argues that 'understanding the ethical significance of nonhuman animals flourishing cannot be differentiated from the flourishing of human beings' (Plannthin 2015: 44). Conclusively, the longevity of fur as material alone seems to be insufficient to align fur and sustainability. However, when looking at the practices around fur, as co-author Skjold and her colleagues did in a recent report, there is evidence that the post-sale phase of the fur life-cycle analysis holds sustainable potentials (Skjold et al. 2016).

Firstly, there is a tradition for careful resource management of materials and a high level of craftmanship and user-closeness embedded in the furrier tradition, which goes against the standardization and mass production of particularly the fast fashion sector. Secondly, there seems to be a special bond between consumers and fur garments that promotes longevity, particularly as they can be handed down through generations. Thirdly, there is a legacy in the history of fur garments pointing back to indigenous people and their respect for nature and animals, which could fuel new and more 'sustainable' perspectives on fur - providing that pre-sale phases of the fur life-cycle analysis become more transparent and controlled. As such, there are inherent values and practices within the fur sector that aligns with ideas in the general discussion about sustainability, particularly ideas related to problems with overproduction and overconsumption in the garment sector at large (e.g. Cooper 2005; Black 2013; Fletcher and Grose 2012). In line with such ideas and arguments, Fur Europe has recently revised its life cycle model for fur, here implementing practices for long-lasting design and use of the garment (see fig. 3) 


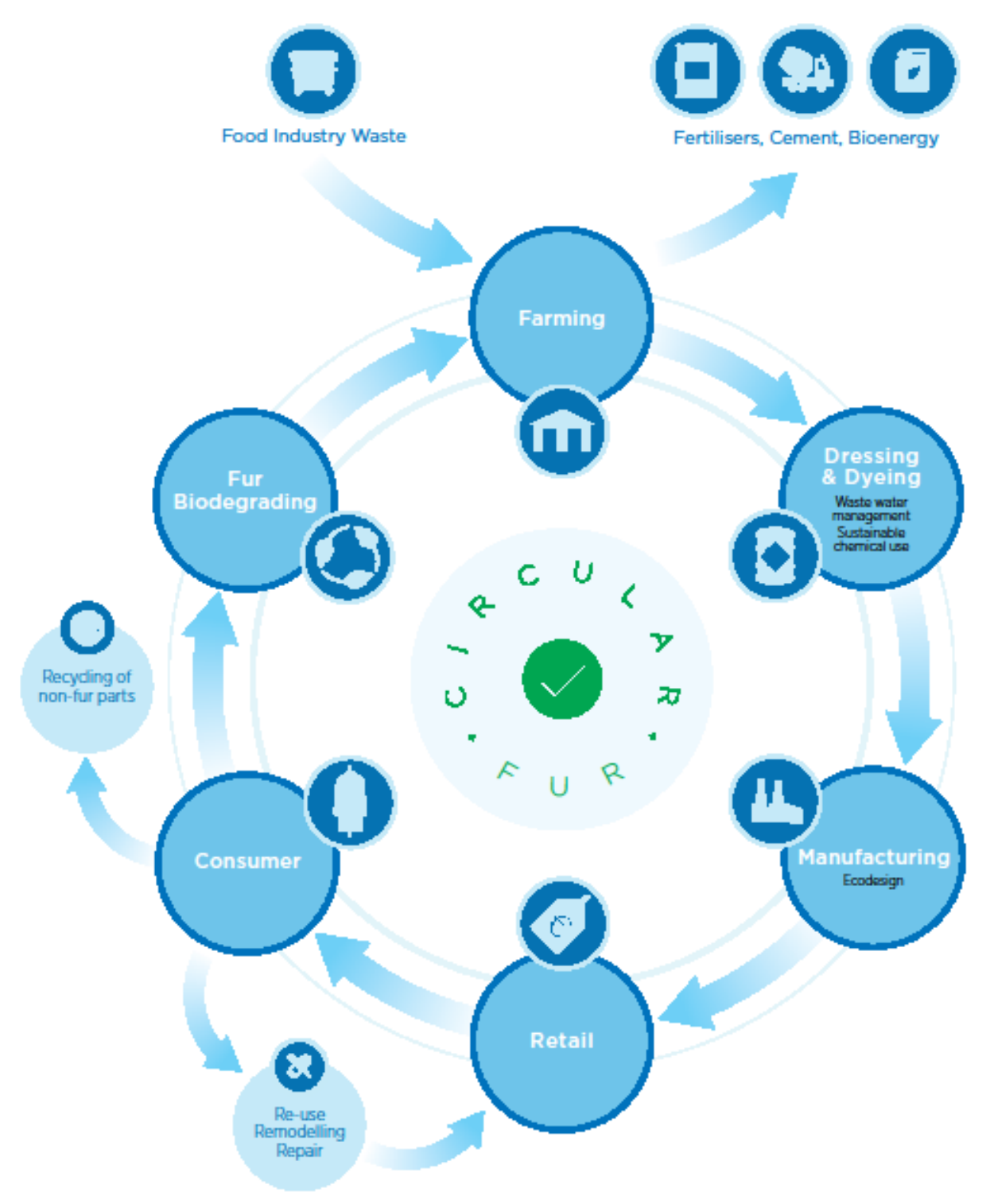

Fig. 3: Model by Fur Europe that illustrates how the fur sector contributes to circular economy in fashion - revised dato de tog det. Illustration shown with kind permission from Fur Europe as of $19^{\text {th }}$ of January 2018.

\section{Conclusion}

In this article, we explain the significance of the notion of 'deeper luxury' in triggering changes in contemporary conversations over luxury. The 'Deeper luxury-report' envisioned a new, enlightened luxury industry, which acknowledges its obligations to society and is committed to making a positive impact in all the communities' it touches. In lashing out at prominent luxury brands, the Report represented a breach of sorts. It implicated the luxury industry in debates over the responsibility for mounting global environmental and social problems - issues that had previously almost always been associated with large, mass consumer brands or other sectors. We suggested that the debates emerging from the confrontation of luxury with sustainability represent 're-moralisation' - a renewal or revival of a tradition for moral criticism of luxury. And as we noted with Hunt (1995), over the ages criticism of luxury has induced regulation, from 
sumptuary laws to more modern forms of governance. In the case of the 'Deeper luxury report', the harsh grading of luxury companies are followed by recommendations for corporate governance initiatives including setting key performance indicators, auditing, monitoring and reporting progress. Current research still debates the extent to which luxury consumer care about sustainability. Some studies indicate no great concern, either due to 'the fallacy of clean luxury' (inference that luxury is above any suspicion) or misrecognition of luxury's environmental and social responsibilities (Davies et. al 2012). Others suggest sustainability represents a latent or implicit 'need', not articulated but expected by aspirational and elite consumers. Sensing, perhaps, that luxury is not immune to stakeholder criticism, which may threaten brands' 'dream image', luxury companies have begun to take sustainability more serious, communicating more actively about their initiatives and committing themselves to further steps.

Godart and Seong's verdict, 'to some extent, in place [...] but for the most part, still to be implemented' (2015: 21), probably represents a fair assessment of where sustainable luxury currently stands. Our study, however, does purport to offer any comprehensive or detailed survey of the luxury industry, but investigates the fur sector in the light of 'deeper luxury' and the emergence of sustainability concerns in luxury.

We have argued that fur, in many ways, incarnates luxury, and explored its historical roots and designation as a marker of social elites (by law, convention or price) as well as its changing symbolic significance over time. The fur business represents a special case: as luxury sector and product category, it has been the target of criticism and controversy since the 1970s - i.e. long before the moral concerns connected to sustainability emerged in the luxury industry. We have suggested that the sustainability agenda by increasing the focus on environmental and social issues in the luxury industry in general might reinforce the anti-fur movement's efforts to end fur. On the other hand, fur is assessed differently through the broader lens of sustainability than that focusing on animal rights. If we consider some of the material qualities and practices associated with fur: durability, natural fibres and degradability, high quality product, craftsmanship, maintenance, care and repair, they fit into the scenario of 'slow luxury fashion' - one of three visions or trajectories of sustainable luxury. The other scenarios, innovative luxury fashion and upgrading through regulation, might either include or exclude fur. Innovations in 'animal welfare technology' and regulation increasing traceability and enforcing of animal welfare standards might help rebuild the legitimacy of fur. Alternatively, luxury might advance beyond fur and stand behind the anti-fur case with its dark vision of luxury as abuse of nature and wildlife for the sake of human vanity and social status. This variety of the innovative luxury scenario could involve further product development of 'faux fur' leading to better imitations of the sensorial qualities of fur, while outperforming real fur on the key environmental indicators. In this case, 'upgrade through regulation' would mean eliminating 'real' fur, rather than attempting to improve animal welfare.

The uncertainty about the place of fur in sustainable luxury - is sustainable fur an oxymoron or legitimate part of a 'deeper luxury' - points to the ambiguities and tensions in the project of sustainable development. Sustainability can be seen as either a delicate balancing act between economic growth, ecological or social equity concerns, or an untenable compromise of either. The animal rights dimension in the fur debate highlights the tensions between anthropocentric and eco-centric orientations, or even between eco-centric and a zoo-centric stance with a stronger 
position on the moral considerability of (non-human) animals. Bendell and Kleanthouse's vision of a 'deeper luxury' evokes the shallowness and vulgarity of luxury as conspicuous display of wealth in their call for a more sustainable luxury. They appeal to noblesse oblige and a more high-minded, tasteful and enlightened form of luxury which reconciles economic, ecological or social imperatives to make a positive change. Fur - with its deep historical roots, complex and changing significations - is a special case, the implications of which, nevertheless, could be applied to other sectors in the luxury industries from leather goods to certain fine foods. We have argued that the case of fur challenges the vision and notion of 'deeper luxury' and questions 'sustainability' as a firm basis on which to make facile, moral judgments about luxuries and the ways they are produced and consumed. If we are to obtain a deeper understanding of sustainable luxury, we need to interrogate of the dynamics of moral problematization and justification as well as the compromises this 'virtuous' version of luxury, inevitably involves.

Kapferer once proposed that the commonplace, but erroneous etymological linkage of luxury to light (lux) as a 'self-justifying semantic manoeuvre': 'if one believes that luxury comes from lux one is ready to accept that like light, luxury is enlightening [...]' (2006: 68). Our study suggests we should pursue the darker sides in the depths of luxury.

\section{References}

Achabou, Mohamed A. and Dekhili, Sihem (2013), 'Luxury and sustainable development: Is there a match?', Journal of Business Research, 66(10), pp. 1896-1903.

Aspesi, Natalia (2000), 'Military Style - The Reappearance of Uniforms in the Icon of Masculinity', in G. Malossi \& H. N. Abrams MATERIAL MAN - masculinity sexuality style, Florence; Pitti Immagine 2000, pp. 148-161.

Bendell, Jem and Kleanthous, Anthony (2007), Deeper Luxury - Quality and Style When the World Matters. London: WWF - UK.

Bendell, Jem and Thomas, Laetitia (2013), 'The Appearance of Elegant Disruption', Journal of Corporate Citizenship, (52), pp. 9-24

Bijleveld, Marijn and Korteland, Marisa (2011), The Environmental Impact of Mink Fur Production. Delft: CE Delft

Black, Sandy (ed.) (2013), The Sustainable Fashion Handbook. London: Thames \& Hudson.

Bolton, Andrew (2005), Wild: Fashion Untamed. Japan: The Metropolitan Museum of Art, New York.

Brennan, Andrew and Lo, Yeuk-Sze, "Environmental Ethics", The Stanford Encyclopedia of Philosophy (Winter 2015 Edition), E. N. Zalta (ed.), 
http://plato.stanford.edu/archives/win2015/entries/ethics-environmental/. Accessed March 30 2016.

Carrigan, M., Moraes, C. and McEachern, M.(2013), 'From conspicuous to considered fashion: A harm-chain approach to the responsibilities of luxury-fashion businesses', Journal of Marketing Management, 29 (11-12), pp. 1277-1307.

Cooper, Tim (2005), 'Slower Consumption: Reflections of product life spans and the "throwaway society"', Journal of Industrial Ecology 9(1-2), pp.51-67.

CSR Wire (2007), 'Media Response to WWF-UK Report on Luxury Brands Could Be Tipping Point for the Industry'. http://www.csrwire.com/press_releases/19950-Media-Response-to-WWF-UKReport-on-Luxury-Brands-Could-Be-Tipping-Point-for-the-Industry-\#. Accessed 1 March 2016.

Dahl, Camilla Luise (2010), Svøbt i mår - pels i middelalderens dragter (Wrapped in marten - Fur in the Middle Ages) Nykøbing F: Middelaldercentret

Daveu, Marie-Claire (2014), 'Placing Sustainability at the Heart of Kering'. The Business of Fashion, 1 October 2014, http://www.businessoffashion.com/articles/bof-500/placing-sustainability-heartkering. Accessed: March 302016

Davies, I. A., Lee, Z. and Ahonkhai, I. (2012), 'Do consumers care about ethical-luxury?', Journal of Business Ethics, 106(1), pp. 37-51.

de Beauvoir, Simone (1989). The Second Sex (1952) (trans. H.M. Parshley), New York: Vintage Books.

Dekhili, Sihem, \& Achabou, Mohamed A. (2016), 'Is It Beneficial for Luxury Brands to Embrace CSR Practices?' in K. K. Kim (ed.) Celebrating America's Pastimes: Baseball, Hot Dogs, Apple Pie and Marketing? New York: Springer International Publishing, pp. 3-18.

Dolin, Eric J. (2011). Fur, fortune, and empire: the epic history of the fur trade in America. New York: Norton \& Company.

Emberly, Julia V. (1998), Venus and Furs. The Cultural Politics of Fur. London: I.B.Tauris.

Entwistle, Joanne. (2014), 'Sustainability and Fashion', in K. Fletcher and M. Tham (eds.), Routledge Handbook of Sustainability and Fashion. UK: Routledge, chapter 2, pp. 18-24.

Fletcher, Kate (2008), Sustainable Fashion \& Textiles. Malta: Earthscan.

Fletcher, Kate and Grose, Lynda (2012), Fashion \& sustainability: design for change. London: Laurence King. 
Gardien, P., Djajadiningrat, J.P.; Hummels, C.C.M. and Brombacher, A.C. (2014), 'Changing your hammer. The Implications of Paradigmatic Innovation for Design Practice', International Journal of Design, 8(2), pp. 119-139.

Gardetti, Miguel. A. and Girón, Maria (eds.) (2014), Sustainable Luxury and Social Entrepreneurship: Stories from the Pioneers. Sheffield: Greenleaf Publishing.

Gardetti, Miguel. A. \& Torres, Ana L. (eds.) (2015), Sustainable Luxury: Managing Social and Environmental Performance in Iconic Brands. Sheffield: Greenleaf Publishing.

Godart, Frédéric and Seong, Sorah (2015), 'Is sustainable luxury fashion possible?' in M. A. Gardetti and A. L. Torres, Sustainable Luxury: Managing Social and Environmental Performance in Iconic Brands. Sheffield: Greenleaf Publishing, pp. 12-27.

Hennigs, N., Wiedmann, K.-P., Klarmann, C. and Behrens, S. (2013), 'Sustainability as Part of the Luxury Essence: Delivering Value through Social and Environmental Excellence. Journal of Corporate Citizenship (52), pp. 25-35.

Hilton, Matthew (2004), "The Legacy of Luxury Moralities of Consumption Since the 18th Century." Journal of Consumer Culture 4.1, pp. 101-123.

Holden, Erling and Linnerud, Kristin (2007), 'The sustainable development area: satisfying basic needs and safeguarding ecological sustainability'. Sustainable Development 15, pp. 174-187.

Hollander, Anne (1994), Sex and Suits. The Evolution of Modern Dress. New York: Alfred A. Knopf

Hopwood, B., Mellor, M. and O'Brien, G. (2005), Sustainable Development: mapping different approaches. Sustainable Development, 13, pp. 38-52.

Hunt, Alan (1995). 'Moralizing luxury: The discourses of the governance of consumption'. Journal of Historical Sociology, 8(4), pp. 352-374.

(1996). 'The Governance of Consumption: Sumptuary Laws and Shifting Forms of Regulation.' Economy and Society 25: pp. 410-27.

IFTF (2012), A Comparative Life Cycle Analysis: Natural Fur and Faux Fur, http://www.wearefur.com/sites/all/themes/iftf/pdf/LCA_final_report.pdf. Accessed 1 March 2016

Imran, S., Alam, K. and Beaumont, N. (2014), 'Reinterpreting the definition of sustainable development for a more ecocentric reorientation'. Sustainable Development, 22(2), pp. 134-144.

Janssen, C., Vanhamme, J., Lindgreen, A., \& Lefebvre, C. (2014), 'The catch-22 of responsible luxury: effects of luxury product characteristics on consumers' perception of fit with corporate social responsibility'. Journal of Business Ethics, 119(1), pp. 45-57. 
Kering (2014), Panorama - A year of sustainability 2013.

http://www.kering.com/sites/default/files/document/kering_panorama_2014.pdf. Accessed 5 March 2016

Kapferer, Jean-Noël (2006). 'The two business cultures of luxury brands'. in J. Schroeder and E. Salzer-Mörling (eds.), Brand culture. London: Routledge, pp. 67-76.

(2010). 'All that glitters is not green: the challenge of sustainable luxury'.

European Business Review, pp. 40-45.

Kapferer, Jean-Nöel and Michaut, Anne (2015). 'Luxury and sustainability: a common future? The match depends on how consumers define luxury'. Luxury Research Journal, 1(1), pp. 3-17.

Kapferer, Jean-Nöel and Michaut-Denizeau, Anne (2014), Is Luxury Compatible with Sustainability; Luxury Consumers' Viewpoint. Journal of Brand Management, 21(1), pp. 1-22.

Kozlowski, A., Bardecki. M. and Searcy, C. (2012), 'Environmental impacts in the fashion industry: A life-cycle and stakeholder framework.' The Journal of Corporate Citizenship 45: 17, pp. 16-36.

Luca, Franco (2014), 'The Luxury Industry in the Wind of Change toward Sustainability'. Building Sustainable Legacies: The New Frontier Of Societal Value Co-Creation, 2014(4), pp. 8-34.

Miller, Jeff (2007), 'CRJP Asks WWF - UK to Withdraw 'Deeper Luxury' Report';

http://www.diamonds.net/News/NewsItem.aspx?ArticlelD=19927. Accessed 1 March 2016.

Moore, Bryony (2011), Style over Substance. Why ethics are not in fashion for designer labels. Manchester: Ethical Consumer Research Association.

Municchi, Anna (1992), Ladies in Furs 1900-1940. The Twentieth Century History of Fashion. Modena: Zanfi Editori.

Olson, Kathryn M. and Goodnight, G. Thomas (1994), 'Entanglements of Consumption, Cruelty, Privacy and Fashion: The Social Controversy over Fur', The Quarterly Journal of Speech, 80 (3), pp. 249-276.

Plannthin Drude-Kathrine (2015), 'Animal Ethics and Welfare in the Fashion and Lifestyle Industries', in S. S. Muthu and M. A. Gardetti (eds.), Green Fashion: Environmental Footprints and Eco-design of Products and Processes, Singapore: Springer, pp. 49-122.

Rocamora, Agnès (2009), Fashioning the City: Paris, Fashion and the Media. London: I.B.Tauris.

Sempels, Christophe. (2012), Sustainable Development in the Luxury Industry: Beyond the Apparent Oxymoron in J. Hoffmann and I. Coste-Manière (eds), Luxury Strategy in Action Palgrave Macmillan UK. pp. 160-181. 
Skjold, E., Ræbild, U., Tanderup, S. and Hasling, K.M. (2016), Fur and Sustainability - a Design Perspective. Report commissioned by Kopenhagen Fur. Kolding: Design School Kolding.

Striet, Carla-Maria and Davies, lain A. (2013), 'Sustainability isn't sexy: an exploratory study into luxury fashion' in M. A. Gardetti and A. L. Torres (eds), Sustainability in fashion and textiles: values, design, production and consumption. Sheffield: Greenleaf Publishing.

Torelli, C. J., Monga, A. B. and Kaikati, A. M.(2012), 'Doing poorly by doing good: Corporate social responsibility and brand concepts', Journal of Consumer Research, 38(5), pp.948-963.

Trentmann Frank (2012), The Oxford Handbook of the History of Consumption. Oxford: Oxford University Press.

World Commission on Environment and Development (1987), Our Common Future. Oxford: Oxford University Press. 